\title{
Description of puparium of Neottiophilum praeustum (Meigen, 1826) (Diptera, Neottiophilidae) with new host species
}

\author{
Agnieszka DrABER-MOŃKO
}

Museum and Institute of Zoology, PAS, Wilcza 64, 00679 Warszawa, Poland; e-mail: draber@miiz.waw.pl

\begin{abstract}
Detailed description and illustration of the puparium of the European nest skipper fly are presented. Information about 8 new hosts is given. The distribution of $N$. praeustum in Poland is presented.
\end{abstract}

Key words: Neottiophilidae, Neottiophilum praeustum, new hosts, puparium, morphology, faunistics, taxonomy, Poland

\section{INTRODUCTION}

The Neottiophilidae are a very small family of the Acalyptratae group of Diptera and their family status has only recently been given. The family contains two genera: Actenoptera Czerny, 1904 with two Palaearctic and one Nearctic species and Neottiophilum Frauenfeld, 1868 with one European species (Schumann 1999, Ozerov 2000a,b, 2005). Neottiophilum praeustum has been recorded from the following countries: Austria, Switzerland, France, Germany, Great Britain, and the North European territory of Russia (Soós 1984), Poland (Nowakowski 1991), the Czech and the Slovak Republics (Doskočil 1960, Zuska \& Barták 1997), Hungary (Papp 2001a) and Norway (Greve \& Olsen 1992). From Poland, there has been recorded only one species - Neottiophilum praeustum (Meigen, 1826), but without more detailed data (Nowakowski 1991: 188) - "Three specimens taken probably in the southern part of Poland, in coll. of S. Kapuściński”.

The larvae of Neottiophilum praeustum are ectoparasites, and live in nests of birds where they feed on the blood of the nestlings. They are often found in open nests of small passerines (Ozerov 2000b). A great number of maggots in one nest causes the death of some or of all nestlings (Zumpt 1965). Imagines were collected on windows, in Malaise traps or rarely, in shady forests and clearings (McAlpine 1977, Soós 1984).

The puparium is formed by the hardening of the $3^{\text {rd }}$ instar cuticle. In most species of Cyclorrhapha the larva retracts its head and contracts its body at pupariation, to produce the typical very ofen barrel-shaped puparium which is different from the longer, thinner, tapered larva. The larval spiracles are normally also clearly visible on the puparium. In most species the puparium retains many characters of the third instar larva. The majority of Diptera the puparia of which are found in birds' nests are parasites. Identification of a particular species of Diptera on the basis of the puparium is very important in ornithological studies.

The 15 species of birds from the nests of which $N$. praeustum has been recorded have been listed by the following authors: Patton (in Keilin 1924) - Chloris chloris (L.), Bezzi (1922) Fringilla coelebs (L,) and Passer domesticus (L.), Keilin (1924) - Carduelis cannabina (L.) and Sylvia atricapilla (L.), Séguy (1934) - Luscinia megaryncha Brehm, Armstrong (1953) Troglodytes troglodytes (L.), Hesse (1923) - Certhia familiaris L. and Turdus merula L., 
Collin (in Keilin (1924) - Turdus philomelos Brehm, Hesse (1925) - Accipiter nisus (L.), Menegaux (1939) - Hypolais icterina (Vieillot), Séguy (1946) - Pica pica (L.), Peus (1960) Corvus corone (L.), and Doskočil (1960) - Carduelis carduelis (L.). These 15 species of birds have also been listed by other authors: Czerny (1930), Tate (1954), Hicks (1959, 1962, 1971), Zumpt (1965), and Colyer \& Hammond (1968).

The immature stages of Neottiophilum praeustum (Meig.) have been described by Hesse (1923), Keilin (1924), Hesse (1925), Tate (1954) and others, but so far the puparium has not been described and illustrated in detail.

The aim of this paper is to provide a more detailed description and illustration of the puparium of Neottiophilum praeustum. The host range of the European nest skipper fly is larger than previously recorded and some more, information on the bird hosts of Neottiophilum praeustum is given. An updated distribution of Neottiophilum praeustum in Poland is presented.

Table 1. European nest skipper fly-Neottiophilum praeustum (Meigen) obtained from nests of varius hosts (bird species) during ornithological research. * - no precise information about the site, $\mathrm{L}$ - number of larvae in host nest, $\mathrm{P}-$ number of puparia in host nest, $\hat{\sigma}$ - number of reared males, $q$ - number of reared females.

\begin{tabular}{|c|c|c|c|c|c|c|c|c|c|}
\hline No & Date & Location & $\begin{array}{l}\text { UTM } \\
\text { code }\end{array}$ & Host & Collector & $\mathrm{L}$ & $\mathrm{P}$ & 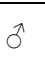 & q \\
\hline 1 & 2 & 3 & 4 & 5 & 6 & 7 & 8 & 9 & 10 \\
\hline 1 & 4.07 .1966 & $\begin{array}{l}\text { Bieszczady, } \\
\text { Tarnica }\end{array}$ & FV 25 & $\begin{array}{l}\text { Prunella modularis } \\
\text { (Linnaeus, 1758) }\end{array}$ & L. Cais & 19 & & & \\
\hline 2 & 10.07 .1969 & $\begin{array}{l}\text { Zakopane, } \\
\text { Kuźnice } \\
\end{array}$ & DV 26 & $\begin{array}{l}\text { Fringilla coelebs } \\
\text { (Linnaeus, 1758) }\end{array}$ & J. Chowaniec & 24 & & & 2 \\
\hline 3 & 10.071969 & $\begin{array}{l}\text { Zakopane, } \\
\text { Kuźnice }\end{array}$ & DV26 & $\begin{array}{l}\text { Turdus torquatus Linnaeus, } \\
1758\end{array}$ & J. Chowaniec & 61 & & & 2 \\
\hline 4 & 8.07 .1969 & $\begin{array}{l}\text { Zakopane, Potok } \\
\text { Olczyski }\end{array}$ & DV26 & $\begin{array}{l}\text { Motacilla cinerea } \\
\text { Thunstall, } 1771\end{array}$ & J. Chowaniec & 7 & & & 1 \\
\hline 5 & 8.07 .1969 & $\begin{array}{l}\text { Majerczykówka } \\
\text { near Poronin }\end{array}$ & DV26 & $\begin{array}{l}\text { Corvus corone cornix } \\
\text { (Linnaeus, 1758) }\end{array}$ & J. Chowaniec & 3 & & & 1 \\
\hline 6 & 26.06 .1969 & Poronin & DV26 & $\begin{array}{l}\text { Turdus pilaris (Linnaeus, } \\
1758 \text { ) }\end{array}$ & W. Skuratowicz & 13 & & & \\
\hline 7 & 21.061971 & Poznań & $*$ & $\begin{array}{l}\text { Turdus merula (Linnaeus, } \\
1758 \text { ) }\end{array}$ & L. Cais & 92 & & & \\
\hline 8 & 06.1971 & $\begin{array}{l}\text { Forest inspecto- } \\
\text { rate Czeszewo } \\
\text { near Mirosław, } \\
\text { district Września }\end{array}$ & XT68 & $\begin{array}{l}\text { Milvus milvus (Linnaeus, } \\
\text { 1758) }\end{array}$ & Z. Lewartowski & 10 & & & \\
\hline 9 & 8.06 .1972 & Ojców & DA16 & $\begin{array}{l}\text { Sylvia atricapilla } \\
\text { (Linnaeus, 1758) }\end{array}$ & A. Nowosad & 17 & & & \\
\hline 10 & 06.1972 & $\begin{array}{l}\text { Forest inspecto- } \\
\text { rate Nekla, } \\
\text { district Września }\end{array}$ & XU70 & $\begin{array}{l}\text { Buteo buteo (Linnaeus, } \\
1758 \text { ) }\end{array}$ & L. Cais & 2 & & & \\
\hline 11 & 28.06 .1973 & Poznań & $*$ & Pica pica (Linnaeus, 1758) & M. Beiger & 3 & & & \\
\hline 12 & 4.06 .1975 & $\begin{array}{l}\text { National Park of } \\
\text { Wielkopolska }\end{array}$ & XT36 & $\begin{array}{l}\text { Carduelis chloris } \\
\text { (Linnaeus, 1758) }\end{array}$ & L. Cais & 12 & & & \\
\hline 13 & 4.06 .1975 & $\begin{array}{l}\text { National Park of } \\
\text { Wielkopolska }\end{array}$ & XT 36 & $\begin{array}{l}\text { Muscicapa striata (Pallas, } \\
\text { 1764) }\end{array}$ & L. Cais & 21 & & & \\
\hline 14 & 06.2004 & $\begin{array}{l}\text { Białowieża } \\
\text { National Park, } \\
\text { Poland }\end{array}$ & FD95 & $\begin{array}{l}\text { Phylloscopus sibilatrix } \\
\text { (Bechstein, 1793) }\end{array}$ & T. Wesołowski & & 70 & 6 & 2 \\
\hline
\end{tabular}


MATERIAL AND METHODS

This study is based on 368 specimens (puparia and adults) of Neottiophilum praeustum reared from many bird nests collected in Poland in different years (1966-1974), in 2003 and 2004. Most of the material (290 specimens) is from the Department of Systematic Zoology, University of Poznań. The detailed information about this material is presented in Table 1. Unfortunately, puparia from Cais's material were thrown away after the emergence of imagines. [Dr. L. Cais died in 1966 and only a small part of his material was published (Cais 1965, Cais et al. 2001)].The puparia used as the basis for the descriptions and for the photographs came from the Białowieża National Park, June, 2004. The puparia were found by T. Wesołowski (Department of Zoology, University of Wrocław) in a nest of the wood warbler Phylloscopus sibilatrix (Bechstein). They were collected after the nestlings had left the nests.

In the Białowieża National Park in 2003 and 2004, 110 nests of Phylloscopus sibilatrix were studied. The study area and the methods are presented in the paper Wesołowski et al. (2006). In the Białowieża National Park in 2004 there were studied 54 nests of Phylloscopus sibilatrix, but puparia and adults of the European nest skipper flies were found only in one nest. In the Białowieża NP. -70 puparia yielded 11 imagines of $N$. praeustum ( 3 of which had not emerged from the puparium (with the head outside and the rest of the body in the puparium).

\section{RESULTS}

In my paper Neottiophilum praeustum was recorded from 14 species of birds (Table 1), and of these: Buteo buteo (L.), Milvus milvus (L.), Motacilla cinerea Thunstall, Muscicapa striata (Pallas), Phylloscopus sibilatrix (Bechstein), Prunella modularis (L.), Turdus pilaris (L.) and T. torquatus L. have been recorded as the hosts of the European nest skipper flies for the first time.

\section{DESCRIPTION OF PUPARIUM}

Pip-shaped, anteriorly pointed, and broadly truncated posteriorly (Figs 1-3), with similar dorsal and ventral sides, but the latter is more flat. About 5.1-7.8 $\mathrm{mm}$ in length and 1.9-3.9 $\mathrm{mm}$ in greatest width. The colour ranges from light brown to black brown. The segmentation is not clearly marked and is partly masked by transverse folds and various protuberances. Some parts of the cuticle of the puparium is thickly (Fig. 12) set with spines, the lengths of which vary in different regions of the body (Figs $4,7 \& 8$ ). The spines of any given region show a wide range in length, but the majority are of similar size (Figs 8 \& 12).

Anterior spiracles of $3^{\text {rd }}$ instar larva fan-shaped entirely open (parallely situated to the surface of puparium), each with 12-14 lobes (Figs 9-11). No pupal respiratory horns. Posterior spiracles sessile, reddish, spiracular plates blackish, small, each with 3 elongate, oval slits, set in a radiating pattern (Figs $15 \& 16$ ). The peritremes of the spiracles are closed. The buttons are situated above the posterior spiracles, these are turned up to the dorsal side. Circumstigmata folds very big and of characteristic forms (Figs 3, 13, 14, 18, 20 \& 21). The distance between the two buttons is twice as long as the diameter of one spiracle.

Cephalopharyngeal skeleton of $3^{\text {rd }}$ instar relatively stoutly built (Figs $17 \& 19$ ), adjoining lower part of puparium. The mouth-hooks are protruding and accompanied laterally by scraperlike structures. No windows shown in dorsal and ventral cornua. Dorsal bridge apparently absent, ventral pharyngeal ridges also absent.

Hesse (1923) recorded an adult of $N$. praeustum emerging from its puparium in a characteristic way (Hesse 1923: fig. 1-3). The phenomenon has also been observed in these studies (Figs 20 \& 21). 

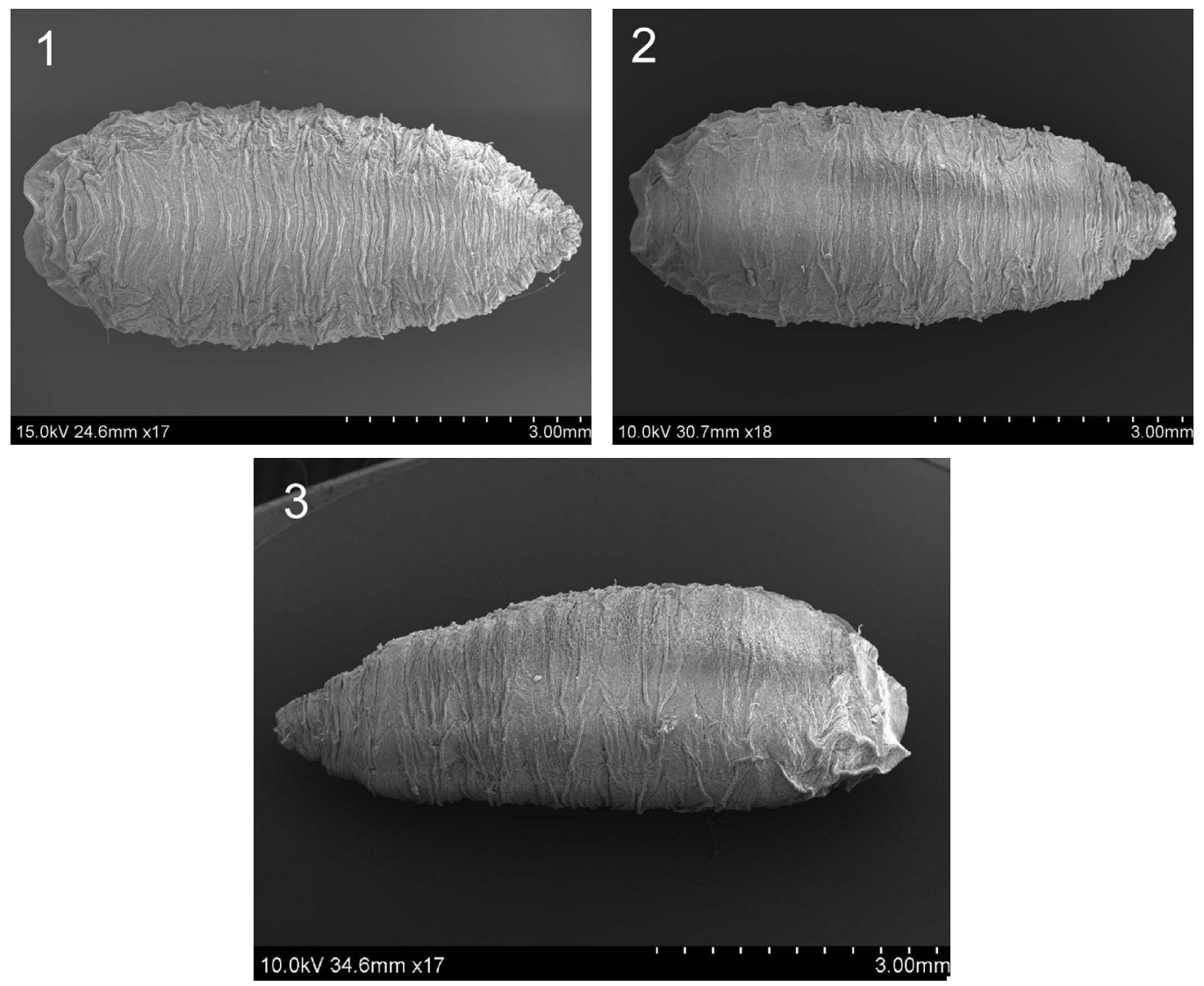

Figs 1-3. Puparium of Neottiophilum praeustum. 1 - dorsal view, 2 - ventral view, 3 - lateral view. (SEM, photo M. Kowalewska).

\section{REMARKS}

Iwasa and Hori (1990) pointed out that the third instar larva described by Rohdendorf (1957) under the name of Protocalliphora azurea (Fallén) was not a Protocalliphora-larva. My present study supports this opinion. In the species of the genus Protocalliphora (Calliphoridae, Calyptratae) the buttons in the $3^{\text {rd }}$ instar larva and the puparium are below the posterior spiracles, since these are turned up to the ventral side. This is well illustrated by Iwasa and Hori (1990: figs 8, 10, 14, 15) and by Cais et al. (2001: figs 9, 17, 25, 30). The buttons and posterior spiracles are situated differently in another parasite of nestlings, namely in the species of the genus Protocalliphora (Calliphoridae). Moreover the puparia in the species of the genus Protocalliphora are barrel-shaped and completely covered with very small spines (Cais et al. 2001). Therefore, in my opinion the third instar larva described by Rohdendorf (1957) as $P$. azurea (Fallén) is, in fact, N. praeustum (Meig.).

The buttons in the $3^{\text {rd }}$ instar larva and the puparium of Neottiophilum praeustum (Meig.) are above the posterior spiracles, since these are turned up to the dorsal side. This is well visible (Figs 13, 15 \& 16) and it was also illustrated by Rohdendorf (1957, fig. 3). The position of the buttons is different in the species of the genus Protocalliphora (Calliphoridae), also parasites of nestlings. 

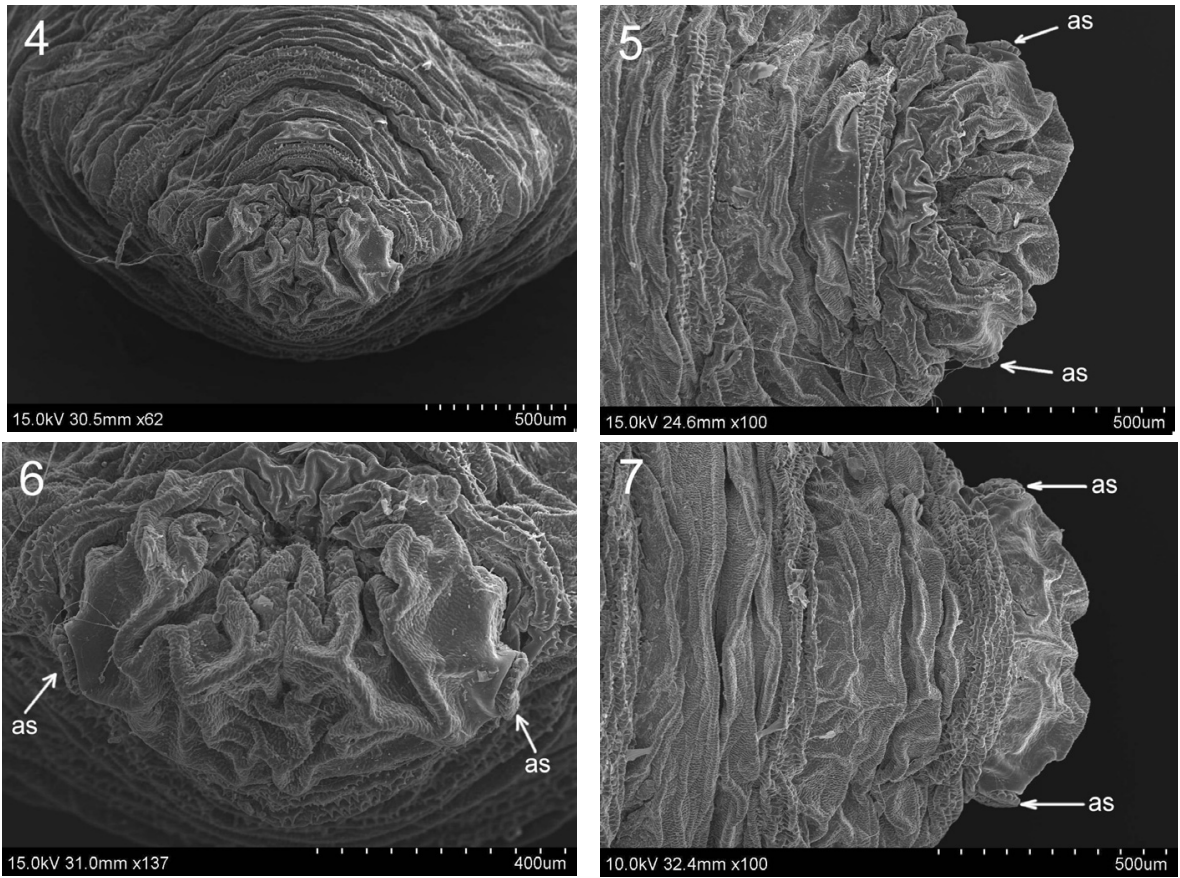

Figs 4-7. Puparium of Neottiophilum praeustum: 4 - anterior part, 5 - anterior part ventrally, 6 - anterior part ventrally, 7 - anterior part dorsally, as - anterior spiracle (SEM, photo M. Kowalewska).
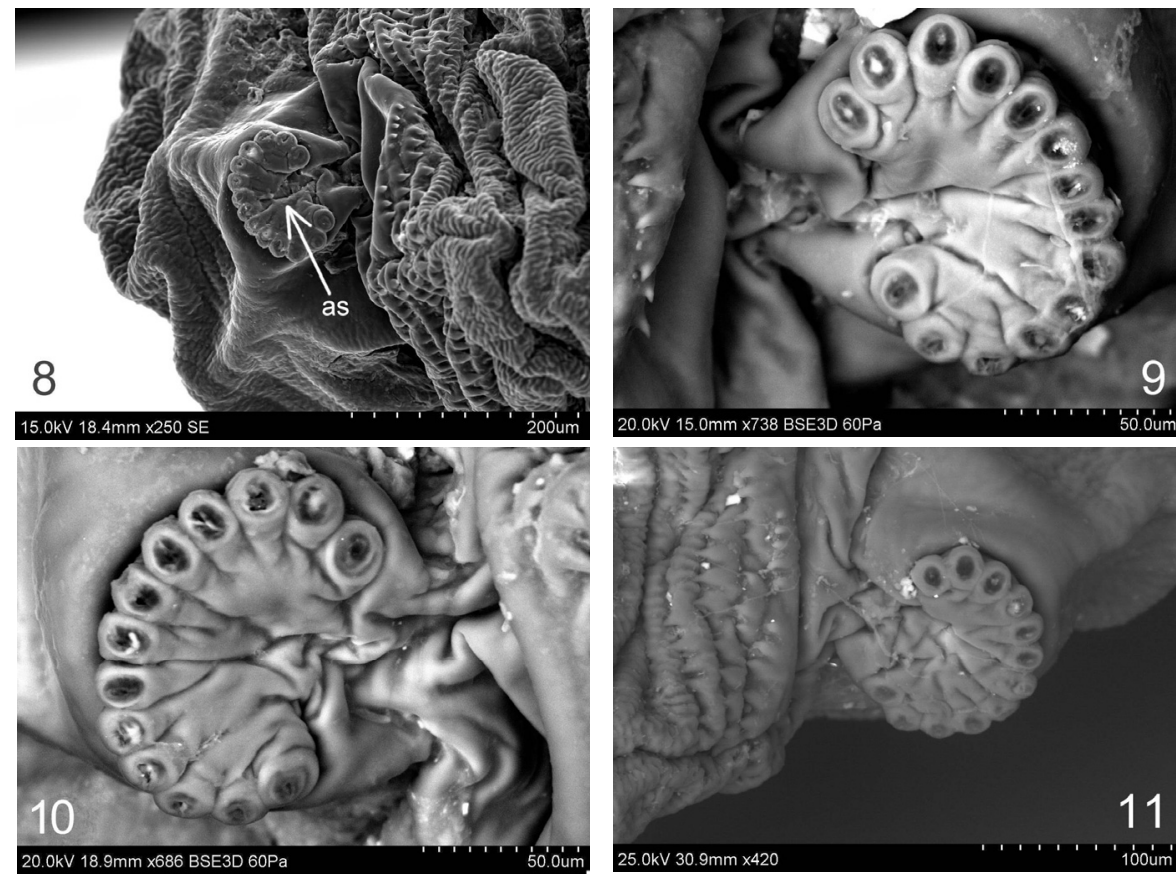

Figs 8-11. Puparium of Neottiophilum praeustum: 8 - anterior part with body folds and spines of 3rd instar larva, laterally, as - anterior spiracles; 9-11 anterior spiracles: 9 - with 14 lobes, 10 - with 13 lobes, 11 - with 12 lobes (SEM, photo M. Kowalewska). 


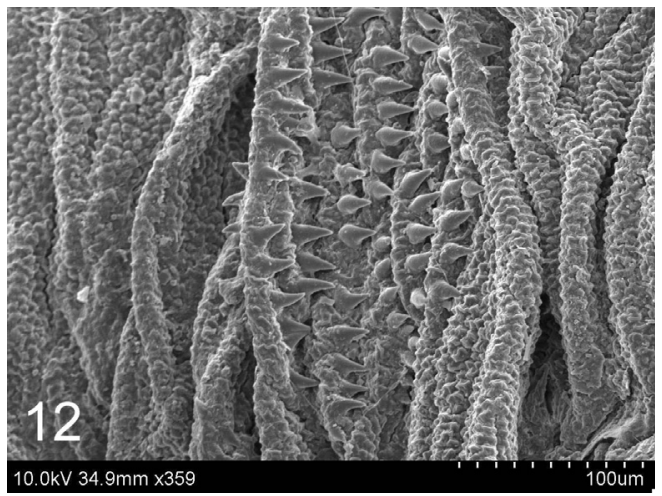

Fig. 12. Puparium of Neottiophilum praeustum, body folds and spines of 3rd instar larva, dorsal side (SEM, photo M. Kowalewska).
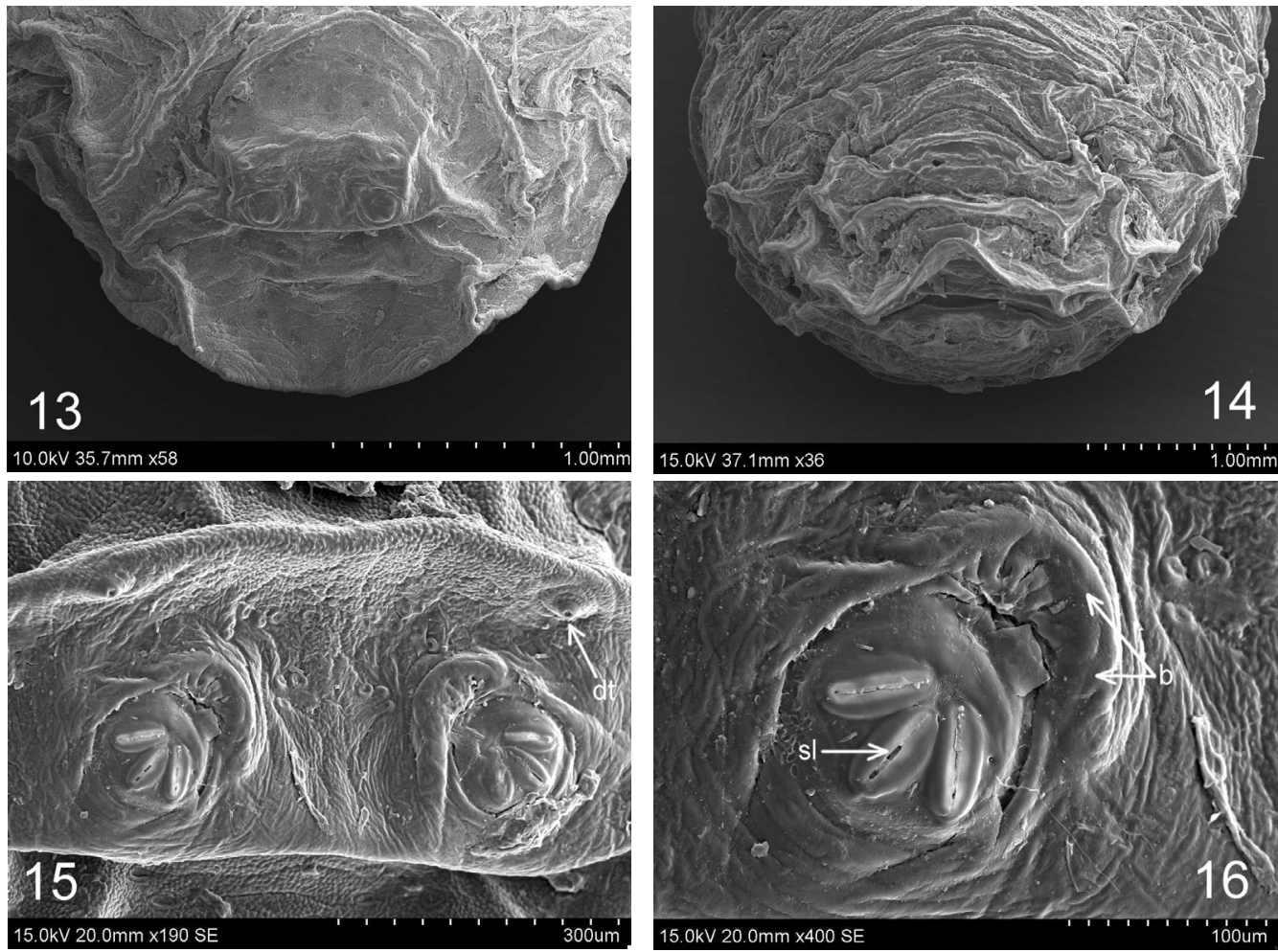

Figs 13-16. Puparium of Neottiophilum praeustum, posterior region: 13 - dorsally, 14 - ventrally; 15-16 posterior spiracles: $d t$ - dorsal tubercle, $s l-$ slit, $b$-button (SEM, photo M. Kowalewska).

\section{ACKNOWLEDGMENTS}

I should like to express my most cordial thanks to Dr Magdalena Kowalewska and Dr Jolanta Wytwer for taking the photographs and to Professors Klara Bartkowska and Tomasz Wesołowski for the materials which made it possible for me to carry out the study for this paper. I am very grateful to Prof. Przemysław Trojan for his critical review of my manuscript and for suggesting several valuable improvements. 

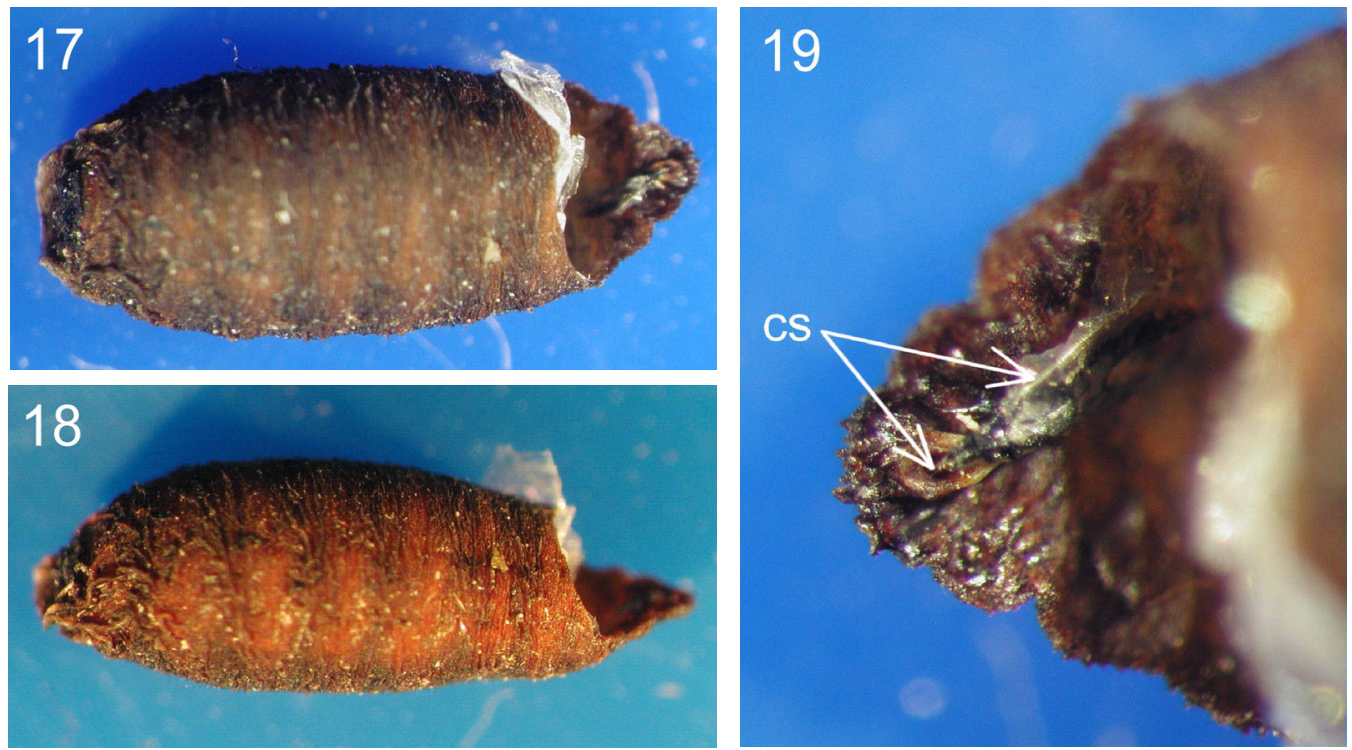

Figs 17-19. Puparium of Neottiophilum praeustum: 17 - empty puparium dorsally, 18 - empty puparium laterally, 19 anterior region dorsally, cs - cephalopharyngeal skeleton of $3^{\text {rd }}$ instar larva (photo J. Wytwer).
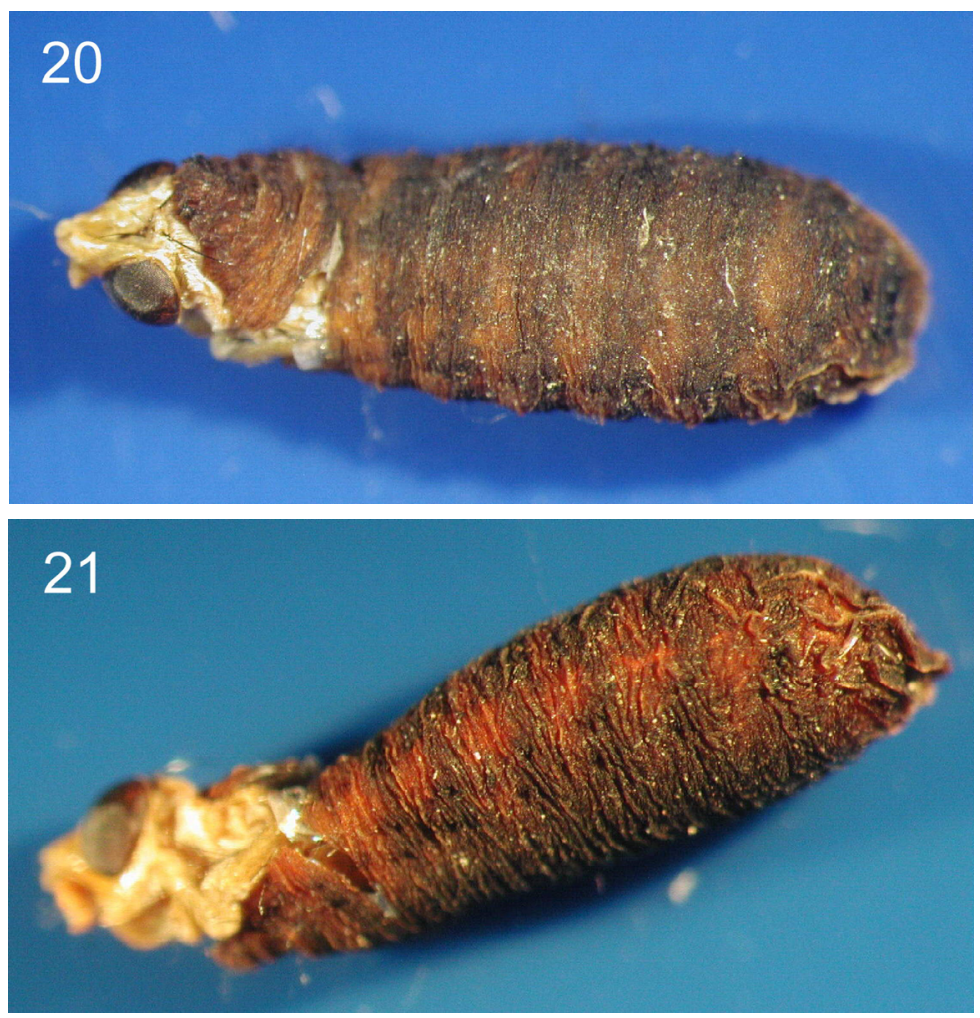

Figs 20-21. Adult of Neottiophilum praeustum emerging from puparium: 20 - dorsally, 21 - laterally (photo J. Wytwer). 


\section{REFERENCES}

ARMSTRONG E. A. 1953. Nidicoles and parasites of the wren. Irish Naturalists' Journal 11: 57-64.

BEZzi M. 1922. On the dipterous genera Passeromyia and Ornithomusca with notes and bibliography on the nonpupiparous Myiodaria parasitic on birds. Parasitology 14: 29-46.

CAIS L. 1965. Protocalliphora hirudo Shannon \& Dobroscky, 1924 (Diptera, Calliphoridae) w Polsce. Fragmenta Faunistica 12: 183-191.

CAIS L, Draber-Mońko A. \& Szpila K. 2001. Bird blowflies (Calliphoridae: Protocalliphora, Trypocalliphora) in Poland. Pol. Pismo Entomol. 70: 277-291.

Colyer C. N. \& HAmmond C. O. 1968. Flies of the British Isles. Frederick Warne \& Co., New York, 384 pp.

CZERNY L.1904. Revision der Helomyziden. I. Teil. Wien. Entomologische Zeitung 23: 199-244.

CZERnY L.1930. 38 b. Neottiophilidae. In: Lindner E. (ed.), Die Fliegen der Palaearktischen Region. E. Schweizerbart'sche Verlagsbuchhandlung. 5: 9-15.

DosKoČIL J. 1960. Nález Neottiophilum praeustum v Čechách. Acta Societatis Entomologicae Cechosloveniae 57: 193-194.

FRAUENFELD G. R. von. 1868. Zoologische Miscellen XV. Verhandlungen der Zoologisch.-Botanischen Gesellschaft 18: 885-902.

GREVE L. \& OlSEN T. J. 1992. Neottiophilum praeustum (Meigen, 1826) (Diptera, Neottiophilidae) new to Norway. Fauna Norv., Ser. B, 39: 89.

HESSE E. 1923. Dipterologische Beiträge. Zeitschrift für wissenschaftlichen Insektenbiologie 18: 293-300.

HESSE E. 1925. Weitere Mitteilungen über Neottiophilum praeustum Meig. Zeitschrift für wissenschaftlichen Insektenbiologie 20: 270-272.

HICKS E. A. 1959. Check-list and bibliography on the occurrence of insects in birds'nest. The Iowa State College Press, $681 \mathrm{pp}$.

HICKS E. A. 1962. Check-list and bibliography on the occurrence of insects in birds'nest. Supplement I. Iowa State Journal of Science, 36: 233-348.

HICKS E. A. 1971. Check-list and bibliography on the occurrence of insects in birds'nest. Supplement II. Iowa State Journal of Science, 46: 123-338.

IWASA M. \& Hori K. 1990. The calliphorid larvae parasitic on birds in Japan (Diptera: Calliphoridae). Med. Vet. Entomol. 4: 141-146.

KEILIN D.1924. On the life history of Neottiophilum praeustum (Meigen 1826) (Diptera-Acalyptratae) parasitic on birds, with some general considerations on the problem of myiasis in plants, animals and man. Parasitology 17:113-126.

MCAlPINE J. F. 1977. A revised classification of the Piophilidae, including 'Neottiophilidae' and 'Thyreophoridae' (Diptera: Schizophora). Mem. Entomol. Soc. Can., 103: 1-66.

MeIGEN J. W. 1826. Systematische Beschreibung der bekannten europäischen zweiflügeligen Insekten. Theil 4:. Schulz \& Wundermann, Hamm, XII+428 pp.+Tab (33-41).

MenegauX A. 1939. Les oiseaux de France. 4. P. Lechevalier, Paris, pp. DCXII-DCCXXXV, 213-402.

Nowakowski J. T. 1991. Neottiophilidae. Vol. 2. In: RAZOWSKi J. (ed.), Checklist of Animals of Poland., p. 188. Ossolineum, Wrocław, $342 \mathrm{pp}$.

Ozerov A. L. 2000a. A. 9. Family Piophilidae. In: PAPP L. \& DARVAS B. (ed.), Contributions to a manual of Palaearctic Diptera (with special reference to flies of economic importance), Appendix, pp. 355-365. Science Herald, Budapest, 604 pp.

Ozerov A. L. 2000b. Novyj vid roda Actenoptera (Diptera, Piophilidae) s Dal'nego Vostoka Rossii. Zool. Zh., 79: $380-381$.

Ozerov A. L. 2005. Fauna Europea. Neottiophilidae. Fauna Europea version1.1., http://faunaeur.org

PAPP L. 2001. Neottiophilidae. In : PAPP L (ed.), Checklist of the Diptera of Hungary, p. 290. Hungarian Natural History Museum, Budapest, $550 \mathrm{pp}$.

PEuS F. 1960. Zur Kenntnis der ornithoparasitischen Phormiinen (Diptera, Calliphoridae) Dtsch. Entomol. Z. 7: 193235.

ROHDENDORF E. B. 1957. On the parasite flies, injurious to nestling singing birds. Entomol. Obozr. 36: 116-124.

SCHUMANN H. 1999. Neottiophilidae. In: SCHUMANN H., BÄHRMANN R. \& STARK A. (eds), Entomofauna Germanica 2. Checkliste der Dipteren Deutschlands, Ampyx-Verlag, Halle (Saale), 354 pp. Studia Dipterologica, Supplement 2: 166 .

SÉGUY E. 1934. Diptères (Brachycères) (Muscidae Acalypterae et Scatophagidae). 28. In: Faune de France. P. Lechevalier, Paris, 832 pp.

SÉGUY E. 1946. Notes biologiques et taxonomiques sur les diptères. 10. In: Encyclopédie entomologique. Série B, pp. 105-150. P. Lechevalier, Paris, 248 pp.

Soós A. 1984. Family Neottiophilidae. In: Soós A. (ed), Catalogue of Palaearctic Diptera. MicropezidaeAgromyzidae. Vol. 9, pp. 241-242. Akadémiai Kiado, Budapest, 460 pp.

TATE P. 1954. Notes upon the biology and morphology of the immature stages of Neottiophilum praeustum (Meigen 1826) (Diptera: Neottiophilidae) parasitic on birds. Parasitology 44: 111-119. 
Wesolowski T., RowiŃski P., Mitrus C. \& CZESZCZEWIK D. 2006. Breeding bird community of a primeval temperate forest (Białowieża National Park, Poland) at the beginning of the $21^{\text {st }}$ century. Acta Ornithologica 41 (1): $55-70$.

ZUMPT F. 1965. Myiasis in man and animals in the Old World. A textbook for physicians, veterinarians and zoologists. Butterworths, London, iv +267 pp.

ZuSKA J. \& BARTÁK M. 1997. Neottiophilinae. In: CHVÁla M. (ed.), Check list of Diptera (Insecta) of the Czech and Slovak Republics, p. 70. Karolinum, Prague, 130 pp.

\section{STRESZCZENIE}

\section{[Opis poczwarki Neottiophilum praeustum (Meigen, 1826) (Diptera, Neottiophilidae) i nowi żywiciele tej muchówki]}

W pracy przedstawiona została bogato ilustrowana morfologia poczwarki, a także larwy trzeciego stadium. Podano również wykaz żywicieli gatunku Neottiophilum praeustum w Polsce.

Wróblinki (Neottiophildae, Diptera) zaliczane do grupy Acalyptrata uzyskały niedawno status rodziny. Na świecie znane są 4 gatunki należące do dwóch rodzajów: Actenoptera Czerny, 1904 oraz Neottiophilum Frauenfeld, 1868. W Europie stwierdzono dwa gatunki z tej rodziny, w Polsce jeden Neottiophilum praeustum. Formy dorosłe są wolnożyjące, natomiast larwy są zewnętrznymi pasożytami, odżywiającymi się krwią piskląt gatunków wróblowatych (Passeriformes). Dotychczas Neottiophilum praeustum stwierdzono w gniazdach 15 gatunków ptaków. W Polsce wróblinki znaleziono w gniazdach 14 gatunków ptaków. U 8 gatunków żywicieli: Buteo buteo (L.), Milvus milvus (L.), Motacilla cinerea Thunstall, Muscicapa striata (Pallas), Phylloscopus sibilatrix (Bechstein), Prunella modularis (L.), Turdus pilaris (L.) i T. torquatus L. stwierdzono $N$. praeustum po raz pierwszy. Larwa III stadium $N$. praeustum (Meig.) została opisana przez Rohdendorf (1957) jako Protocalliphora azurea (Fall.) (Diptera, Calliphoridae). 